УДК 342.7

DOI: https://doi.org/10.47567/bomivit.1-3.2020.04

$$
\begin{array}{r}
\text { О. О. Боярський, } \\
\text { кандидат юридичних наук }
\end{array}
$$
докторант Інституту законодавства Верховної Ради України суддя Білгород-Дністровського міського суду

Одеської області boyarskii.oleksandr@gmail.com ORCID: https:// orcid.org/0000-0003-3725-1703

Б. Я. Кофман, кандидат юридичних наук головний науковий співробітник Інституту законодавства Верховної Ради України Заслужений юрист України kofman.borys@gmail.com ORCID: https:/ / 0000-0003-0599-9143

\title{
ПРАВА, СВОБОДИ ТА ОБОВ'ЯЗКИ ЛЮДИНИ І ГРОМАДЯНИНА ЯК ЗМІСТ КОНСТИТУЦЙНО-ПРАВОВОГО СТАТУСУ
}

\author{
O. O. Boyarsky, \\ $\mathrm{PhD}$ in Law \\ Doctoral Candidate at the Legislation Institute of \\ The Verkhovna Rada of Ukraine \\ Judge of Bilhorod-Dnistrovskyi city-raion court of Odessa oblast \\ boyarskii.oleksandr@gmail.com \\ ORCID: https://orcid.org/0000-0003-3725-1703
}

B. Ya. Kofman, $\mathrm{PhD}$ in Law Chief researcher Legislation Institute of The Verkhovna Rada of Ukraine Honored Lawyer of Ukraine kofman.borys@gmail.com ORCID: https:/ / 0000-0003-0599-9143

\section{RIGHTS, FREEDOMS AND DUTIES OF A MAN AND A CITIZEN AS THE CONTENT OF CONSTITUTIONAL AND LEGAL STATUS}


Стаття присвячена розгляду прав, свобод та обов' язків людини і громадянина як змісту іï конституційно-правового статусу. Спочатку автор коротко аналізує поняття конституційно-правового статусу особи, окреслюючи деякі проблеми його розуміння. В подальшому досліджуються категорії конституційного права, свободи та обов'язку людини і громадянина, а також проводиться їх співвідношення між собою. Зазначено, що найбільш розповсюдженим критерієм поділу конституційних прав і свобод людини і громадянина є сфера життєдіяльності суспільства. В цьому 3в' язку конституційно закріплені права та свободи людини і громадянина поділяють на громадянські (особисті), політичні, економічні, соціальні, культурні.

Відзначена важливість переходу від декларативної зафіксованості прав, свобод та обов’язків особи в Конституції України до їх реалізовуваності. Визначено, що права і свободи людини як елементи конституційно-правового статусу мають спільні основи закріплення, гарантування, охорони та захисту, однак різняться реалізацією (права потребують певних механізмів чи засобів, а свободи не потребують). При цьому свобода людини є категорією фундаментальною щодо права людини. В свою чергу, обов'язок людини і громадянина являє собою міру необхідної поведінки особи, мінімальні вимоги, які висуваються державою до особи. В силу своєї природи обов'язок особи має більшою мірою позитивний характер, а тому потребує чіткої регламентації в законодавстві. Важливість обов'язку як елементу конституційноправового статусу людини і громадянина полягає в утіленні його превентивної функції, завдяки якій шкода інтересам особи, суспільства та держави не повинна бути нанесена.

Ключові слова: право людини, свобода людини, конституційний обов' язок, конституційно-правовий статус, Конституція України.

The article is devoted to the consideration of human and civil rights, freedoms and responsibilities as the content of its constitutional and legal status. First, the author briefly analyzes the concept of constitutional and legal status of the person, outlining some problems of its understanding. The categories of constitutional rights, freedoms and duties of man and citizen are further studied, as well as their relationship between them. It is noted that the most common criterion for the separation of constitutional rights and freedoms of man and citizen is the sphere of society. In this regard, the constitutionally enshrined rights and freedoms of man and citizen are divided into civil (personal), political, economic, social, cultural.

The importance of the transition from the declarative fixation of the rights, freedoms and responsibilities of a person in the Constitution of Ukraine to their implementation is noted. It is determined that human rights and freedoms as elements of the constitutional and legal status have common bases of consolidation, guarantee, protection and defense, but differ in implementation (rights require certain mechanisms or means, and freedoms do not need). At the same time, human freedom is a fundamental category in relation to human rights. In turn, the duty of man and citizen is a measure of the necessary behavior of the person, the minimum requirements imposed by the state on the person. Due to its nature, a person's duty is more positive and therefore requires clear regulation in law. The importance of duty as an element of the constitutional and legal status of a person and a citizen lies in the implementation of its preventive function, due to which the interests of the individual, society and the state should not be harmed. 
Keywords: human rights, human freedom, constitutional duty, constitutional and legal status, the Constitution of Ukraine.

Постановка проблеми. Питання про правовий статус особи постає одним із фундаментальних у рамках кожної галузі права. Вказаний постулат випливає із закріпленого в ст. 3 Конституції України положення про те, що «права і свободи людини та їх гарантії визначають зміст і спрямованість діяльності держави», а більше того, що головним обов' язком держави постає «утвердження і забезпечення прав і свобод людини» [1]. В такий спосіб права і свободи людини являють собою центральну категорію права як такого. При цьому слід зауважити, що феномен правового статусу особи є дещо ширшим, адже, з точки зору теорії права, охоплює, окрім прав і свобод, ще й обов'язки особи, відповідальність, гарантії прав і свобод тощо. Те ж саме стосується поняття конституційно-правового статусу, що має спеціально галузевий щодо поняття правового статусу характер.

Передусім значимість дослідження саме конституційно-правового статусу пов'язана зі зв'язком з Конституцією України як Основним законом держави. Завдяки цьому варто вести мову про фундаментальність галузі конституційного права в системі галузей українського права. Незважаючи на визначену широту категорії правового статусу особи, а так само конституційно-правового статусу людини і громадянина, базовими елементами, що й визначають їх зміст, постають права, свободи та обов' язки. 3 одного боку, права і свободи, а з іншого - обов' язки особи (людини і громадянина) демонструють водночас деяке протистояння одне 3 одним та взаємодоповнюваність. Загальноприйнятим $є$ положення про неможливість функціонування прав і свобод без обов'язків, а обов'язків без прав і свобод. Визначені обов'язки особи забезпечують стримування в реалізації прав і свобод людини, не дають їм можливості перейти в стан свавілля. В свою чергу, права і свободи особи щодо обов'язків дозволяють вповні реалізувати свободу індивіда в суспільстві, можливості до самоствердження, суспільної та індивідуальної активності.

На сьогодні актуальність дослідження розглядуваної нами проблематики можливо простежити крізь призму ставлення та поведінки українського суспільства до визначених прав, свобод та обов'язків людини і громадянина. Попри незначний перелік зафіксованих в Конституції України обов'язків, останні виконуються неналежним чином, натомість значний перелік прав і свобод, що має переважно декларативний характер, продукує дисбаланс між закріпленими правами і свободами та можливістю їх реалізації, в тому числі й з боку держави. Тому в подальшому перелік прав і свобод людини та громадянина повинен отримати своє збалансоване зосередження й більш ретельну регламентацію в рамках Основного закону, зокрема зважаючи на принцип прямої дії Конституції України.

Аналіз останніх досліджень і публікацій. Проблема конституційноправового статусу людини і громадянина, а так само таких його елементів як права, свободи та обов'язки залишається достатньо дослідженою в Україні. Серед провідних науковців у цій сфері дослідження варто відзначити: С. П. Головатого,
В. С. Журавського,
А. М. Колодій,
О. Г. Кушніренка,
Л. І. Летнянчина, А. Ю. Олійника, В. Ф. Погорілка, П. М. Рабіновича, М. В. Савчина, Ю. М. Тодику, В. Л. Федоренка, М. О. Фокіну, Т. А. Француз-Яковець, О. Ф. Фрицького та інших. Однак на сьогодні необхідним $є$ нове «прочитання» конституційних прав, свобод та 
обов' язків, виведення нових смислів, наближення до реалій суспільного життя.

Метою статті є з'ясування сутність прав, свобод та обов'язків людини і громадянина як змісту ії конституційно-правового статусу, а також співвідношення даних елементів правового статусу між собою.

Виклад основного матеріалу. Зважаючи на обмеженість обсягу нашого дослідження, автор одразу перейде до короткого розгляду поняття конституційноправового статусу особи, минаючи більше загальне щодо нього поняття правового статусу особи, визначене в теорії права. Так, українські вчені В.Ф. Погорілко та В.Л. Федоренко розглядають конституційно-правовий статус людини і громадянина як загальний правовий статус поряд зі спеціальним та індивідуальним. Він визначається конституцією держави та конституційними законами, а в його основі лежать конституційні права, свободи та обов'язки людини і громадянина. Важливою характеристикою конституційно-правового статусу науковці називають рівність людини і громадянина перед законом, тобто незалежність від різного роду показників і статусів для того, щоб могли бути реалізованими права, свободи та обов' язки [4, с. 35-36].

В свою чергу, Ю.М. Тодика та В.С. Журавський також наголошують на єдності, однаковості для всіх конституційного (загального) статусу людини і громадянина. Вченими підкреслюється статичний і узагальнений характер такого правового статусу, а його змістом - права та обов' язки, надані й гарантовані всім Конституцією України [3, с. 118].

3 точки зору О.Ф. Фрицького, конституційно-правовий статус особи являє собою загальні, основоположні засади, за допомогою яких у Конституції визначаються основні права, свободи та обов' язки людини і громадянина, а також гарантії їх здійснення, тобто можливість мати, володіти, користуватися i розпоряджатися економічними, політичними, культурними та іншими соціальними цінностями, благами, користуватися свободою дій і поведінки в межах конституції та інших законів. В основі такого статусу особи фактичний соціальний статус особи як вся сукупність економічних, політичних, духовних, моральних та інших умов життя суспільства [9, с. 120-121].

Зі вказаних вище розумінь конституційно-правового статусу людини і громадянина спостерігається деякою мірою їх однобоке тлумачення, яке концентрується на самій особі, а також необхідності забезпечити ії права, свободи, інтереси тощо, гарантовані Основним законом держави. При цьому не охоплюється ширший контекст усвідомлення важливості окреслення конституційного статусу особи в його зв'язку 3 суспільними реаліями, функціонуванням держави, особливостями правової системи тощо. Деякою мірою ширше тлумачення конституційно-правового статусу людини і громадянина дається Т.А. ФранцузЯковець, яка слушно зазначає, що в цьому понятті відбувається фіксація основ взаємовідносин між людиною, державою і суспільством, позначаються їх права та взаємні обов'язки, встановлюється система забезпечення, гарантування й захисту прав усіх учасників указаних взаємовідносин [8, с. 14].

Цілком можливо допустити, що подібне однобоке розуміння конституційноправового статусу людини і громадянина й сприяє тому, що в Україні сфера прав, свобод і обов'язків, зокрема в їх кореляції між собою, залишається досить розбалансованою. Саме через те, що законодавцем не враховано контекстів суспільного, державного розвитку, соціально-економічних умов, політичної ситуації 
тощо, що, з нашої точки зору, фундаментально важливі в якості факторів реалізації відповідного комплексу прав, свобод та обов'язків людини і громадянина, визначених Конституцією України. Необхідним є перехід від декларативної зафіксованості прав, свобод та обов'язків особи до їх реалізовуваності. А остання можлива лише в зв'язку з тими конкретними аспектами соціальної реальності, які мають місце на певному етапі розвитку держави та суспільства.

Перед тим як безпосередньо перейти до аналізу прав, свобод та обов'язків людини і громадянина як елементів конституційно-правового статусу особи, зазначимо, що саме ці структурні елементи отримують загальне схвалення науковців. Інші ж елементи конституційно-правового статусу (гарантії прав і свобод, принципи тощо) різняться в підходах дослідників.

Можливо погодитись 3 М.В. Савчином у тому, що права людини й основоположні свободи складають фундаментальну конституційну цінність, а їх гарантії постають змістом діяльності правової держави й критерієм легітимності дії органів держави [5, с. 244]. 3 точки зору В.Ф. Погорілка та В.Л. Федоренка, права людини являють собою іiі можливості, необхідні для нормального існування та розвитку як особистості, певні невід'ємні можливості особистої свободи, вільної життєдіяльності в суспільстві. В свою чергу, свободи людини також відображають ії можливості, однак відрізняються від прав засобами здійснення та забезпечення. Мова йде про те, що здійснення прав людини переважно можливе завдяки наявним механізмам, юридичним засобам, визначених у державі. В свою чергу, свободи людини мають в своєму фундаменті вільне самовизначення особи, i, зазвичай, подібних засобів чи механізмів не потребують [4, с. 43-45].

Таким чином, права і свободи людини мають спільні основи закріплення, гарантування, охорони та захисту, однак різняться реалізацією: права потребують певних механізмів чи засобів, а свободи не потребують. Так, закріплене в ст. 43 Конституції України право на працю необхідним чином вимагає наявності підприємств, установ, організацій, фондів зайнятості тощо, організація яких значною мірою покладається на державу. В той час як, наприклад, свобода думки і слова (ст. 34 Конституції України) особливих механізмів чи засобів для ії реалізації не потребує. Людина від природи наділена здатністю до мови, а тому свобода думки і слова логічно слідує з цієї природної даності. Виходячи з такого аналізу, можна вказати, що, порівняно з правами, свободи людини володіють вищим ступенем самодостатності, вони більшою мірою наближені до природи людини. В той час як права людини переважно являють собою поєднання природного та позитивного підходів.

Погодимось з Н.В. Федіною в тому, що свободи людини являють собою ті сфери ії діяльності, в які держава не може втручатися, а лише має право окреслити кордони (територію), в межах яких людина діє на власний розсуд і за власним вибором. Звідси, отже, ми виходимо на розуміння свободи як категорії фундаментальної щодо права людини. Тому й слушним є визначення права людини як унормованої свободи. Право водночас постає умовою забезпечення та захисту свободи людини й універсальним інструментом ії̈ обмеження [7, с. 70-72].

При цьому мають місце й спільні характеристики прав і свобод людини. Серед них зокрема: 1) передбачають можливість діяти задля забезпечення існування, розвитку й задоволення основних потреб; 2) юридично визначене право вибору певної поведінки; 3) можливості людини обумовлені рівнем розвитку соціуму 
(економічного, політичного, духовного тощо); 4) мають не колективний, а індивідуальний характер [2, с. 187].

Слід наголосити, що українське законодавство (якщо його розглядати за галузевим принципом) містить значну кількість прав і свобод людини. Безпосередня регламентація останніх, більше того, складає основну частину нормативно-правових актів, які видаються в Україні. Однак особливість конституційних прав та свобод людини і громадянина полягає в їх фундаментальності, адже, саме в силу їх зафіксованості в рамках Основного закону, вони наділяються статусом «непорушності». Окрім цього, інші права й свободи, визначені різного роду актами законодавства, повинні відповідати чи хоча б не суперечити визначеним Конституцією України правам і свободам людини і громадянина.

Зібрані в Основному законі держави права і свободи людини і громадянина носять систематизований, деякою мірою впорядкований характер, вони захищені особливим ступенем правової охорони. Формулювання «конституційні права та свободи людини і громадянина» не $є$ випадковим, адже справді всю множину прав і свобод людини поділяється на права i свободи людини та права і свободи громадянина. Кожне положення Розділу II Конституції України, регламентуючи ті чи інші права та свободи, чітко фіксує належність останніх - вони стосуються людини чи громадянина.

Не вдаючись до розширеної класифікації конституційних прав і свобод людини і громадянина, зазначимо лише, що найбільш розповсюдженим критерієм їх поділу є сфера життєдіяльності суспільства. В цьому зв'язку конституційно закріплені права та свободи людини і громадянина поділяють на громадянські (особисті), політичні, економічні, соціальні, культурні.

Обов'язки людини i громадянина як невід'ємний елемент змісту конституційно-правового статусу особи, хоча й тісно пов'язані з правами та свободи, все ж відрізняються від останніх завдяки специфіці їх реалізації. Мова йде про те, що обов'язки не мають прямої дії, а для їх виконання необхідне законодавче регулювання, накладання відповідних повноважень на органи влади щодо контролю за їx здійсненням. Тому зміст конституційного обов'язку потребує конкретизації в рамках поточного законодавства [5, с. 382-383].

Ю.М. Тодика та В.С. Журавський визначають конституційний обов'язок як встановлену державою в інтересах усіх членів суспільства і закріплену в Конституції необхідність, що встановлює кожному громадянину відповідний вид i міру поведінки, а також відповідальність за неналежне ії виконання [3, с. 122].

Точніше та ширше визначає конституційний обов' язок людини і громадянина О.Ф. Фрицький: це закріплене в конституційно-правових нормах формальновиражене правило належної поведінки людини, яке застосовується до будь-яких осіб, що перебувають на території держави, або до поведінки громадян даної держави, незалежно від місця їх перебування, 3 метою запобігти нанесенню непоправної шкоди державі, суспільству, правам і свободам інших людей [9, с. 170]. Значимість такого розуміння конституційного обов' язку пояснюється тим, що воно містить вказівку на мету регламентації обов'язку - не допустити (запобігти) спричинення шкоди інтересам особи, суспільства та держави.

Обов' язок в силу своєї природи, на відміну від прав і свобод (виражають міру можливої поведінки), визначає міру необхідної поведінки, тобто такої, яка повинна бути здійснена особою в силу законодавчого припису. Окрім цього, на відміну від 
прав, обов'язки мають більшою мірою позитивний характер, а тому повинні бути чітко регламентовані законодавцем. Якщо право людини показує ії можливості, то обов'язки - обмеження вказаних можливостей. При цьому не можна погодитись 3 М.В. Савчином у тому, що обов'язки є «тінню прав людини» [5, с. 382]. Подібно ж можна було б назвати права людини «тінню обов'язків», адже існування прав без обов'язків, i, навпаки, обов'язків без прав у рамках демократичної держави неможливе. Права та обов'язки взаємно доповнюються, і лише завдяки такій взаємодоповнюваності можлива повноцінна реалізація особи в суспільстві. Адже суспільство передбачає необхідність взаємодії значної кількості індивідів, а тому права та обов'язки повинні гармонійно поєднуватись. Складно й, мабуть, упереджено було б сказати, що обов'язки слідують з прав людини. Цілком тоді ймовірно вказати, що й права людини слідують з ії обов' язків.

Права та обов' язки людини в рамках конституційно-правового статусу особи відрізняються також метою свого закріплення. Якщо метою регламентації прав $\epsilon$ забезпечити можливості для реалізації людини, ііі інтересів у суспільстві та державі в різних сферах та аспектах, то ціль регламентації обов' язків - запобігти нанесенню шкоди інтересам інших людей, суспільству чи державі. Отже, приходимо до висновку, що важливість обов'язку як елементу конституційно-правового статусу людини і громадянина полягає в утіленні його превентивної функції, завдяки якій шкода інтересам не повинна бути нанесена.

В рамках Розділу II Конституція України передбачає наявність всього кількох обов'язків людини і громадянина: захищати Вітчизну, незалежність та територіальну цілісність України; шанувати державні символи України (ст. 65); не заподіювати шкоду природі, культурній спадшині, а також відшкодовувати завдані цим збитки (ст. 66); сплачувати податки й збори в порядку, передбаченому законом (ст. 67); неухильно додержувати Конституції України та законів України; не посягати на права і свободи, честь і гідність інших людей (ст. 68) [1]. Виходячи з такої фіксації конституційних обов'язків, їх можливо розподіляти на позитивного («сплачувати», «відшкодовувати» тощо) та негативного («не заподіювати», «не посягати» тощо) характеру. Окрім цього, мають місце активні (захист Вітчизни, сплата податків і зборів тощо) та пасивні (не заподіювати шкоду природі, не посягати на права i свободи інших людей тощо) обов'язки.

Обмеженість переліку конституційних обов'язків поряд із правами та свободами людини пояснюється тим, що перші являють собою мінімальні вимоги, які висуваються державою до особи. Така мінімізація обов'язків, слід наголосити, характерна саме для демократичних держав [6, с. 390]. Протилежна ж ситуація має місце за тоталітарних режимів (абсолютизму) - мінімізація прав та розширення сфери обов' язків.

Висновки. Таким чином, ми виявили дещо обмежений погляд наукової спільноти на розуміння поняття конституційно-правового статусу особи, яке зосереджується лише на людині, не враховуючи конкретних аспектів соціальної реальності на певному етапі розвитку держави та суспільства. Тому на сьогодні вкрай важливим є перехід від декларативної зафіксованості прав, свобод та обов'язків особи в Конституції України до їх реалізовуваності. Ми також визначили, що права i свободи людини як елементи конституційно-правового статусу мають спільні основи закріплення, гарантування, охорони та захисту, однак різняться реалізацією (права потребують певних механізмів чи засобів, а свободи не потребують). При 
цьому свобода людини є категорією фундаментальною щодо права людини. В свою чергу, обов'язок людини і громадянина являє собою міру необхідної поведінки особи, мінімальні вимоги, які висуваються державою до особи. В силу своєї природи обов'язок особи має більшою мірою позитивний характер, а тому потребує чіткої регламентації в законодавстві. Важливість обов'язку як елементу конституційноправового статусу людини і громадянина полягає в утіленні його превентивної функції, завдяки якій шкода інтересам особи, суспільства та держави не повинна бути нанесена.

\section{Список використаних джерел:}

1. Конституція України від 28.06.1996 р. № 254к/96-ВР. Відомості Верховної Ради України. 1996. № 30. Ст. 141.

2. Клімова Г.П. Права і свободи людини в Україні: класифікація, гарантії реалізації. Державне будівництво та місиеве самоврядування. 2006. Вип. 11. С. 184193.

3. Конституційне право України: Підручник для студентів вищих навчальних закладів / за ред. Ю. М. Тодики, В. С. Журавського. Київ : Видавничий Дім «Ін Юре», 2002. 544 с.

4. Погорілко В. Ф., Федоренко В. Л. Конституційне право України: Академічний курс : підруч. У 2 т. Т. 2. Київ : Юридична думка, 2006. 800 с.

5. Савчин М. В. Конституційне право України: підручник / відп. ред. М. О. Баймуратов. Київ : Правова єдність, 2009. 1008 с.

6. Сирота Д. І. Обов'язки громадян як один із центральних елементів їх правового статусу. Форум права. 2009. № 2. С. 389-393.

7. Федіна Н.В. Сучасні погляди на розуміння прав і свобод людини та громадянина в умовах реформування в Україні. Науковий вісник Львівського державного університету внутрішніх справ. Серія юридична. 2015. № 4. C. 65-74.

8. Француз-Яковець Т. А. Забезпечення конституційно-правового статусу людини і громадянина в Україні: автореферат дисертації кандидата юридичних наук. Одеса, 2007. 19 с.

9. Фрицький О. Ф. Конституційне право України : підручник. Київ : Юрінком Інтер, 2002. 536 с.

\section{References:}

1. Konstytutsiia Ukrainy 1996 [Constitution of Ukraine 1996] (Verkhovna Rada Ukrainy) [(Verkhovna Rada of Ukraine)]. Vidomosti Verkhovnoi Rady Ukrainy [Information of the Verkhovna Rada of Ukraine], 30, 141. [in Ukrainian].

2. Klimova, H. P. (2006). Prava i svobody liudyny v Ukraini: klasyfikatsiia, harantii realizatsii [Human rights and freedoms in Ukraine: classification, guarantees of implementation]. Derzhavne budivnytstvo ta mistseve samovriaduvannia [State and local government building], iss. 11, 184-193. [in Ukrainian].

3. Todyka, Yu. M., Zhuravskyi, V. S. (ed.) (2002). Konstytutsiine pravo Ukrainy: pidruchnyk dlia studentiv vyshchykh navchalnykh zakladiv [Constitutional law of Ukraine: a textbook for students of higher educational institutions]. Kyiv: Vydavnychyi Dim «In Yure». [in Ukrainian].

4. Pohorilko, V. F., Fedorenko, V. L. (2006). Konstytutsiine pravo Ukrainy: 
Akademichnyi kurs: pidruchnyk [Constitutional law of Ukraine: Academic course: textbook]. In 2 vol. Vol. 2. Kyiv: Yurydychna dumka. [in Ukrainian].

5. Savchyn, M. V. (2009). Konstytutsiine pravo Ukrainy: pidruchnyk [Constitutional law of Ukraine: textbook]. Kyiv: Pravova yednist. [in Ukrainian].

6. Syrota, D. I. (2009). Oboviazky hromadian yak odyn iz tsentralnykh elementiv yikh pravovoho statusu [Responsibilities of citizens as one of the central elements of their legal status]. Forum prava [Law Forum], no. 2, 389-393. [in Ukrainian].

7. Fedina, N. V. (2015). Suchasni pohliady na rozuminnia prav i svobod liudyny ta hromadianyna $\mathrm{v}$ umovakh reformuvannia $\mathrm{v}$ Ukraini [Modern views on the understanding of human and civil rights and freedoms in the context of reform in Ukraine]. Naukovyi visnyk Lvivskoho derzhavnoho universytetu vnutrishnikh sprav. Seriia yurydychna [cientific Bulletin of Lviv State University of Internal Affairs. The series is legal], no. 4, 65-74. [in Ukrainian].

8. Frantsuz-Yakovets, T. A. (2007). Zabezpechennia konstytutsiino-pravovoho statusu liudyny i hromadianyna $v$ Ukraini: avtoreferat dysertatsii kandydata yurydychnykh nauk [Ensuring the constitutional and legal status of man and citizen in Ukraine: Thesis Candidate of Legal Sciences]. Odesa. [in Ukrainian].

9. Frytskyi, O. F. (2002). Konstytutsiine pravo Ukrainy: pidruchnyk [Constitutional law of Ukraine: textbook]. Kyiv: Yurinkom Inтеp. [in Ukrainian]. 